\title{
Instytucja porozumienia małżonków o sposobie wykonywania władzy rodzicielskiej i utrzymywaniu kontaktów z dzieckiem po rozwodzie w kontekście kodeksowej regulacji niedozwolonych postanowień umownych
}

Przedmiotem artykułu jest instytucja porozumienia małżonków posiadających co najmniej jedno wspólne małoletnie dziecko, tworzonego w toku postępowania rozwodowego, rozpatrywana w kontekście regulacji kodeksu cywilnego ${ }^{1}$ odnoszącej się do tak zwanych niedozwolonych postanowień umownych. Rozważania otwiera charakterystyka planu wychowawczego ${ }^{2}$, ze szczególnym uwzględnie-

Ustawa z dnia 23 kwietnia 1964 r. Kodeks cywilny (T.j. Dz.U. z 2014 r., poz. 121 ze zm.) (dalej: k.c).

2 Pojęcia „porozumienie małżonków” oraz "plan wychowawczy” należy traktować jako synonimiczne. Pomimo zbieżności znaczeniowej, pierwszy z terminów, obecny w przepisach kodeksu rodzinnego i opiekuńczego zwraca uwagę raczej na fakt współdziałania małżonków w sprawach związanych ze sprawowaniem pieczy rodzicielskiej. Drugie $\mathrm{z}$ ujęć, prezentowane w poglądach doktryny oraz w orzecznictwie sądów powszechnych akcentuje, z kolei, aspekt pedagogiczny, wskazujący na potrzebę możliwie wszechstronnej regulacji sytuacji dziecka po zakończeniu postępowania rozwodowego. 
niem przesłanek jego sporządzenia, warstwy przedmiotowej oraz roli klauzuli dobra dziecka. Przeprowadzona analiza pozwala na ocenę przydatności wskazanej instytucji w kontekście regulacji sytuacji dziecka po orzeczeniu rozwodu oraz wyodrębnienie obszarów wymagających doprecyzowania legislacyjnego. W dalszej kolejności prezentacji podlega kodeksowa regulacja systemu niedozwolonych postanowień umownych obejmujących stosunki prawne z udziałem konsumentów, zwłaszcza w odniesieniu do abstrakcyjnej kontroli ich legalności. Przeprowadzone rozważania dają asumpt do analizy problemu głównego, jakim jest możliwość przetransponowania, na drodze analogii sui generis, wybranych rozwiązań ustawodawczych związanych z funkcjonowaniem rejestru klauzul abuzywnych ${ }^{3}$ na grunt prawnorodzinnych analiz związanych z konstrukcją porozumienia małżonków. Artykuł zamyka próba teoretycznej oceny przydatności rozwiązania tego rodzaju z uwzględnieniem poszczególnych podmiotów uczestniczących w postępowaniu lub objętych jego skutkami.

\section{Instytucja planu wychowawczego na gruncie polskiego prawa rodzinnego}

Przesłanki dla wprowadzenia do polskiego systemu prawa instytucji porozumienia małżonków wskazuje rządowy projekt ustawy o zmianie ustawy - kodeks rodzinny i opiekuńczy oraz niektórych innych ustaw ${ }^{4}$. W opinii inicjatorów przyjętych zmian legislacyjnych, istnieje wyraźna potrzeba dostosowania unormowań kodeksu rodzinnego

Pojęcia „niedozwolonych postanowień” umownych i „klauzul abuzywnych" należy traktować jako równoznaczne.

4 Rządowy projekt ustawy o zmianie ustawy - Kodeks rodzinny i opiekuńczy oraz niektórych innych ustaw z dnia 12 sierpnia 2008 r. (druk nr 888). 
i opiekuńczego ${ }^{5} \mathrm{w}$ zakresie sytuacji prawnej dziecka i stosunków między rodzicami i dziećmi do ratyfikowanych przez Polskę umów, przepisów Konstytucji Rzeczypospolitej Polskiej, rekomendacji organizacji międzynarodowych ${ }^{6}$, jak również postulatów formułowanych na gruncie judykatury oraz doktryny prawa rodzinnego ${ }^{7}$. Idea porozumienia stron w zakresie podstawowych kwestii regulujących funkcjonowanie dziecka po rozwodzie częściowo powiela amerykańskie rozwiązanie legislacyjne ${ }^{8}$, przewidujące tworzenie, na drodze zgodnego współdziałania stron, planów wychowawczych ${ }^{9}$ stanowiących konkretyzację zobowiązań wychowawczych małżonków ${ }^{10}$. Przedstawienie sądowi projektu tego rodzaju już na etapie postępowania rozwodowego ma zabezpieczać przyszłą sytuację dziecka, a ponadto zwiększać efektywność kontroli wykonania postanowień porozumienia. Regulację taką z całą pewnością należy ocenić jako przydatną, formalnie chroniącą osobę dziecka w trudnej sytuacji rozpadu dotychczasowego modelu funkcjonowania rodziny.

Instytucja porozumienia małżonków została wprowadzona do k.r.o. nowelą z 2008 roku $^{11}$, uzupełniając do-

5 Ustawa z dnia 25 lutego 1964 r. Kodeks rodzinny i opiekuńczy (T.j. Dz.U. z 2012 r., poz. 788 ze zm.) (dalej: k.r.o).

6 Por. Recommendation No. R (84) 4 of the Committee of Ministers to Member States on Parental Responsibilities, Principle 6.

Rządowy projekt ustawy..., dz. cyt.

8 Więcej na temat amerykańskiego systemu prawa rodzinnego w odniesieniu do instytucji planu wychowawczego zob. W. Stojanowska, Postulat przeniesienia koncepcji „planu wychowawczego" rozwodzacych się rodziców na grunt prawa polskiego, „Zeszyty Prawnicze UKSW" nr 7.2, s. 12nn.

9 Funkcjonujących również pod pojęciem „planów wychowawczych rodziców", akcentującym aktywny udział małżonków w regulacji sytuacji dziecka po rozwodzie. Zob. tamże, s. 7.

10 Zob. tamże, s. 14.

11 Ustawa z dnia 6 listopada 2008 r. o zmianie ustawy - Kodeks rodzinny i opiekuńczy oraz niektórych innych ustaw (Dz.U. z 2008 r. Nr 220, poz. 1431). 
tychczasową regulację dotyczącą postępowania rozwodowego. W obowiązującym stanie prawnym, w wyroku orzekającym rozwód małżonków posiadających co najmniej jedno wspólne małoletnie dziecko ${ }^{12}$, sąd rozstrzyga kwestię władzy rodzicielskiej, kontaktów z dzieckiem po zakończeniu procedury rozwodowej oraz obowiązków związanych z ponoszeniem kosztów utrzymania i wychowania dziecka. Elementy te mają charakter obligatoryjny, co oznacza, że sytuacja małoletniego dziecka stron postępowania musi zostać uregulowana w treści wyroku ${ }^{13}$. Dla omawianej instytucji kluczowego znaczenia nabiera fragment artykułu $58 \$ 1$ k.r.o., stanowiący, że sąd uwzględnia porozumienie rodziców o sposobie wykonywania władzy rodzicielskiej i utrzymywaniu kontaktów z dzieckiem po rozwodzie, jeżeli jest ono zgodne z dobrem dziecka ${ }^{14}$. Co istotne, przedłożenie planu stanowi element konieczny w przypadku małżonków dążących do utrzymania pełnej władzy rodzicielskiej nad dzieckiem po orzeczeniu rozwodu ${ }^{15}$.

Uwagę zwraca nieprecyzyjna redakcja wskazanego przepisu w zakresie instytucji planu wychowawczego. Lapidarne sformułowanie zawarte $\mathrm{w}$ przepisach k.r.o. generuje sporo niejasności interpretacyjnych w odniesieniu do kwestii formalnych i proceduralnych oraz skutków prawnych, jakie wywołuje porozumienie małżonków. Można domniemywać, że intencją ustawodawcy było odstąpienie od precyzyjnego uregulowania problematyki planów

12 Przepis obejmuje ponadto dzieci przysposobione przez obydwoje małżonków oraz dziecko jednego z małżonków przysposobione kolejno przez drugiego. Zob. Rozwód i separacja. Komentarz, red. J. Ignaczewski, Warszawa 2010, s. 43. Dla uproszczenia pojęcia „dziecko” i „małoletni” należy traktować jako terminy synonimiczne, spełniające przesłankę kodeksową przesłankę pokrewieństwa.

13 Zob. K. Gromek, Komentarz do artykutu 58 KRO, Legalis, Warszawa 2013.

14 Zob. art. $58 \$ 1$ k.r.o., zdanie drugie.

15 Zob. art. $58 \mathbb{\$} 1$ a k.r.o., zdanie drugie. 
wychowawczych. Za takim stanowiskiem opowiada się część przedstawicieli doktryny, podnosząc, że w toku prac legislacyjnych celowe niedookreślenie warstwy przedmiotowej porozumienia zwyciężyło nad propozycją zawężenia jego formy i treści ${ }^{16}$. Przyjęte rozwiązanie z całą pewnością komplikuje proces tworzenia planu. Z drugiej strony, pozostawienie w rękach rozwodzących się małżonków ograniczonej nadzorem sądu autonomii w kwestii treściowej zawartości porozumienia można uznać za okoliczność potencjalnie sprzyjającą optymalnemu zabezpieczeniu przyszłej sytuacji dziecka.

$\mathrm{Na}$ skutek zaledwie ramowej regulacji instytucji planu wychowawczego, na gruncie doktryny i orzecznictwa podejmowane są próby określenia funkcji ${ }^{17}$, jakie powinna spełniać konkretyzacja nowego modelu funkcjonowania rodziny. Przede wszystkim porozumienie ma ułatwiać uporządkowanie rzeczywistości porozwodowej poprzez rozważenie dostępnych opcji działania oraz analizę praw i obowiązków rodziców wobec dziecka. Poprzez uszczegółowienie postanowień dotyczących sprawowania władzy rodzicielskiej i utrzymywania kontaktów z dzieckiem realizuje się normatywny wymiar planu. Regulacja sytuacji dziecka po sądowym orzeczeniu rozwodu pełni, ponadto, funkcję edukacyjną, wyrażającą się w poszerzaniu wiedzy rodziców na temat ich relacji względem dziecka. Szczegółowe zaplanowanie funkcjonowania rodziny po rozwodzie posiada również walor prewencyjny, ukierunkowany na zapobieganie powstawaniu konfliktów w trakcie postępowania rozwodowego i po jego zakończeniu, a także

16 Zob. T. Sokołowski, Komentarz do art. 58 KRO, Wolters Kluwer Polska, Warszawa 2013.

17 Wyliczenie za: H. Ciepła, Nowelizacje Kodeksu rodzinnego i opiekuńczego z komentarzem, Lexis (edycja elektroniczna), Warszawa 2010. Por. W. Stojanowska, Postulat przeniesienia koncepcji..., dz. cyt., s. 19-20. 
angażowaniu w nie małoletniego dziecka rozwiedzionych małżonków.

W aktualnym stanie prawnym porozumienie małżonków obejmuje dwa podstawowe zagadnienia - dookreślenie sposobu sprawowania władzy rodzicielskiej oraz kontaktów z dzieckiem po orzeczeniu rozwodu. Wskazane przez ustawodawcę elementy znajdują rozwinięcie w przepisach k.r.o. Pod pojęciem władzy rodzicielskiej należy rozumieć kompleks praw i obowiązków składających się na relację rodziców wobec osoby i majątku małoletniego dziecka, obejmujący, w szczególności, dbałość o jego wychowanie ${ }^{18}$. Kontakty z dzieckiem ${ }^{19}$ zakładają, z kolei, przebywanie z dzieckiem oraz bezpośrednie i pośrednie porozumiewanie się. Podkreślenia wymaga, że kodeksowa definicja wskazanych terminów ma charakter zaledwie przykładowy. Nie sposób sporządzić wyczerpującego wyliczenia czynności składających się na wykonywanie władzy rodzicielskiej i utrzymywanie kontaktów z dzieckiem. Wykładnia wskazanych terminów powinna każdorazowo uwzględniać indywidualną sytuację dziecka oraz rodziny, mając na uwadze nadrzędną klauzulę dobra małoletniego.

Co do zasady, plan wychowawczy ma mieć charakter kompletny ${ }^{20}$. Treściowa zawartość porozumienia małżon-

18 Art. $95 \$ 1$ k.r.o., por. Wtadza rodzicielska i kontakty z dzieckiem. Komentarz, red. J. Ignaczewski, Warszawa 2012, s. 6.

19 Co szczególnie istotne, utrzymywanie kontaktów z dzieckiem stanowi prawo niezależne od powierzenia wykonywania władzy drugiemu z rodziców, z wyłączeniem przypadku ograniczenia lub pozbawienia władzy rodzicielskiej. Zob. Wyrok Sądu Najwyższego z dnia 30 września 1980 r. (II CR 277/80).

20 Przepisy kodeksu rodzinnego i opiekuńczego nie rozstrzygają problemu konstrukcji i przedłożenia sądowi zaledwie części planu. $\mathrm{Na}$ gruncie literatury przedmiotu podnosi się, że porozumienie nie traci swojej skuteczności nawet gdy brak w nim rozstrzygnięć precyzujących którąś z dwóch głównych składowych planu, jak również w sytuacji pozostawienia pewnych kwestii do dalszego uzgodnienia. Zob. T. Sokołowski, Komentarz do art. 58 KRO, dz. cyt. 
ków powinna obejmować całość funkcjonowania dziecka po orzeczeniu rozwodu. Pomimo braku kodeksowej definicji zakresu przedmiotowego omawianej instytucji, na gruncie doktryny wskazuje się na konieczność uwzględnienia w porozumieniu kilku podstawowych płaszczyzn. Do katalogu elementów planu ${ }^{21}$ zaliczyć można atrybut wychowania, kierowania, zabezpieczenia środowiska materialnego, troski o osobę dziecka, pieczy nad majątkiem, koordynacji rozwoju dziecka oraz określenia postaci kontaktów ${ }^{22}$. Każda ze wskazanych sekcji powinna znajdować rozwinięcie w postaci konkretnych ustaleń określających prawa i obowiązki rodziców względem dziecka celem optymalnego zabezpieczenia interesu tego ostatniego. Podkreślenia wymaga, że pomimo istnienia doktrynalnych sugestii ${ }^{23}$ związanych z przedmiotową warstwą porozumienia, plan wychowawczy stanowi przedsięwzięcie o wysokim stopniu złożoności, wymagające dokładnego rozpoznania potrzeb dziecka, powinności małżonków, jak również sposobu funkcjonowania rodziny po orzeczeniu rozwodu.

Postulat możliwie szczegółowego uregulowania sytuacji dziecka po rozwodzie z całą pewnością sprzyja optymalizacji funkcjonowania małoletniego, realizując zarazem funkcje wskazywane na gruncie doktryny prawa rodzinnego. Mając na uwadze sformułowanie instytucji porozumienia na gruncie kodeksu, należy uznać, że ciężar doprecyzowania treściowej zawartości planu wychowawczego przeniesiony został z ustawodawcy na rodziców ${ }^{24}$. Takie rozwiązanie

21 Wyliczenie za: tamże.

22 Por. M. Araszkiewicz, A. Łopatkiewicz, A. Zienkiewicz, Factor-Based Parent Plan Support System, [w:] ICAIL 2013 - The Fourteenth International Conference on Artificial Intelligence and Law. Proceedings of the Conference, ed. B. Verheij, E. Francesconi, A. Gardner, New York 2013, s. 172-173.

23 Zob. T. Sokołowski, Komentarz do art. 58 KRO, dz. cyt.

24 Przy utrzymaniu kontrolnej funkcji sądu w odniesieniu do realizacji wymogu zgodności porozumienia z dobrem dziecka. 
niewątpliwie sprzyja dostosowaniu projektowanych rozstrzygnięć do sytuacji konkretnego dziecka. In abstracto, doświadczenie rodziców w odniesieniu do funkcjonowania ich dziecka pozwala na stworzenie planu nieporównywalnie lepiej dostosowanego do potrzeb dziecka, niż ma to miejsce w przypadku władczego rozstrzygnięcia sądu dysponującego ograniczoną wiedzą na temat stanu faktycznego. Z drugiej strony, rozwód stanowi zdarzenie o charakterze kryzysowym, z podłożem w postaci konfliktu ${ }^{25}$, który przynajmniej częściowo rozstrzygnąć ma orzeczenie sądu o rozwiązaniu małżeństwa. W takiej sytuacji konstruktywne podejście do kwestii związanych z podziałem władzy rodzicielskiej i zaplanowaniem przyszłego funkcjonowania rodziny stanowi okoliczność stosunkowo rzadką ${ }^{26}$, potęgowaną dodatkowo brakiem klarownej, możliwie wyczerpującej instrukcji usprawniającej proces tworzenia planu wychowawczego.

Jak wynika z językowej stylizacji art. 58 k.r.o., inicjatorami sporządzenia i zawarcia porozumienia przedkładanego sądowi są rozwodzący się małżonkowie. Są oni zarazem twórcami planu wychowawczego, co oznacza, że na drodze współdziałania możliwie szeroko rozstrzygają kwestie dotyczące wspólnego małoletniego dziecka. W realizacji tego zadania strony sporu mogą napotkać przeszkody dwojakiego rodzaju. Pierwsza polega na konieczności zawieszenia konfliktu małżonków nierzadko towarzyszącego postępowaniu rozwodowemu, w celu koncentracji na kryterium dobra dziecka ${ }^{27}$. Druga wiąże się z trudnością

25 Zob. A. Łopatkiewicz, Klauzula generalna dobra dziecka - wsparcie czy przeszkoda $w$ rozwiązywaniu konfliktów na tle rozwodowym?, [w:] Rozwiązywanie sytuacji konfliktowych $w$ wymiarze jednostkowym i społecznym, red. M. Plucińska, Poznań 2014, s. 149nn.

26 Podobnie niski odsetek stanowi liczba spraw z zakresu prawa rodzinnego zakończonych w wyniku postępowania mediacyjnego, zakładającego koncyliacyjne nastawienie stron sporu. Zob. tamże.

27 Okoliczność współdziałania stron posiada wpływ na decyzję sądu o utrzymaniu przez oboje małżonków władzy rodzicielskiej. W aktualnym stanie prawnym wystąpienie okoliczności uzasadniających 
w określeniu i doprecyzowaniu całokształtu sytuacji życiowej dziecka po orzeczeniu rozwodu. Pomimo uzasadnionego przypuszczenia, że rodzice stanowią najlepsze źródło wiedzy na temat własnego dziecka, od rozwodzących się małżonków nie sposób oczekiwać specjalistycznego przygotowania z zakresu pedagogiki i psychologii przydatnych przy planowaniu sytuacji dziecka. O ile w odniesieniu do przesłanki współdziałania, kluczowego znaczenia nabiera wzajemne nastawienie małżonków przy świadomości korzyści wynikających z przyjęcia postawy koncyliacyjnej, o tyle w przypadku merytorycznej zawartości planu kompetencje małżonków mogą okazać się niewystarczające. Chociaż przepisy kodeksu expressis verbis nie stanowią o wsparciu rodziców dążących do stworzenia porozumienia przez instytucje zewnętrzne, pogląd taki jest powszechnie podnoszony na gruncie doktryny prawa rodzinnego. W celu uzyskania profesjonalnej pomocy pedagogicznej, psychologicznej i prawnej strony postępowania mogą się zwrócić do placówek świadczących usługi mediacyjne oraz doradcze ${ }^{28}$. Należy przy tym podkreślić, że gotowość małżonków do przyjęcia wsparcia tego rodzaju w dużej mierze uzależniona jest od konstruktywnego podejścia do problemu współdziałania w kreowaniu przyszłej sytuacji dziecka.

oczekiwanie, że małżonkowie nie będą współpracować w kwestiach związanych z dzieckiem, stanowi jeden z warunków odrzucenia wniosku o pozostawienie rodzicom pełnej pieczy nad małoletnim potomstwem. Podkreślenia wymaga, że przyjęte rozwiązanie, w teorii optymalizujące interes dziecka, w praktyce może doprowadzić do sytuacji, w której małżonek intencjonalnie niweczy przesłankę współdziałania, co prowadzi do konieczności ograniczenia władzy rodzicielskiej jednej ze stron postępowania. Por. K. Gromek, Komentarz do artykutu $58 \mathrm{KRO}$, dz. cyt.

28 W szczególności rodzinnych ośrodków diagnostyczno-konsultacyjnych. W stworzeniu porozumienia mogą również służyć wiedzą i wsparciem pełnomocnicy stron postępowania. Zob. T. Sokołowski, Komentarz do art. $58 \mathrm{KRO}$, dz. cyt.. 
W ujęciu modelowym porozumienie przygotowane przez małżonków ma pierwszeństwo ${ }^{29} \mathrm{w}$ stosunku do władczego rozstrzygnięcia sądu o sposobie sprawowania władzy rodzicielskiej i o utrzymywaniu kontaktów. Należy przy tym podkreślić, że warunkiem sine qua non możliwości zaakceptowania przez sąd w wyroku rozwodowym treści przedłożonego planu jest jego zgodność z „dobrem dziecka" ${ }^{30}$. Pojęcie to nie posiada swojej ustawowej definicji. Mając na względzie konieczność każdorazowego, szczegółowego rozpoznania sytuacji konkretnego dziecka przy ocenie warunków realizacji jego dobra, ustawodawca odstąpił od przyjęcia enumeratywnego zbioru wytycznych precyzujących przedmiotowy zakres omawianego terminu. W efekcie dobro dziecka funkcjonuje na gruncie polskiego prawa rodzinnego jako klauzula generalna o charakterze odsyłającym ${ }^{31}$, której interpretacja, poza wskazanym aspektem indywidualizacji, w warstwie przedmiotowej wymaga odwołania się do szeregu przesłanek o charakterze prawnym oraz pozaprawnym ${ }^{32}$.

Na gruncie orzecznictwa dobro dziecka utożsamia się z modelową sytuacją małoletniego. Zgodnie ze stanowiskiem Sądu Najwyższego, „ten idealizacyjny model zakłada, że dziecko wychowuje się w rodzinie - najlepiej

29 Prymat koncyliacyjnego porozumienia rodziców nad adjudykacyjnym rozstrzygnięciem sądu wynika z przyjęcia modelu, w którym decyzja sądu zastępująca porozumienie małżonków stanowi ostateczny środek zabezpieczenia interesu małoletniego, stosowany w przypadku braku inicjatywy rodziców lub sprzeczności przedłożonego planu z klauzulą dobra dziecka. Wskazanej ingerencji wymiaru sprawiedliwości nie należy mylić z sądową kontrolą porozumienia dokonywaną obligatoryjnie przed orzeczeniem wyroku rozwodowego małżonków posiadających wspólne dziecko.

30 Odzwierciedleniem pojęcia "dobro dziecka” na gruncie aktów prawa międzynarodowego jest „interes dziecka”. Oba terminy traktować należy jako synonimiczne.

31 Więcej na temat klauzuli generalnej odsyłającej dobra dziecka zob. tamże.

32 W szczególności pedagogicznym i psychologicznym. 
naturalnej - w każdym razie w ustalonej sytuacji prawnorodzinnej, w atmosferze miłości, w warunkach pozwalających zaspokoić rozsądnie pojmowane jego potrzeby i najpełniej rozwijać jego talenty i zdolność samodzielnego, twórczego działania oraz kształtować charakter w duchu określonych ideałów. Istotne jest przy tym jego ukierunkowanie nie tylko na aktualną sytuację dziecka, lecz także na jego przyszłość”33. Przytoczony opis pozwala wnioskować, że pojęcie dobra dziecka odnosić należy do całokształtu jego funkcjonowania, z uwzględnieniem teraźniejszej i przyszłej perspektywy, jak również potrzeby odpowiedniego ukształtowania bezpośredniego środowiska dziecka. Wytyczna Sądu Najwyższego, jakkolwiek formułuje pewne ramy brzegowe myślenia o dobru dziecka, nie ułatwia wyodrębnienia zbioru aktywności, których realizacja tożsama jest działaniem $\mathrm{w}$ interesie małoletniego. Wskazany stan rzeczy, w zamyśle ustawodawcy korzystny z uwagi na potrzeby małoletniego dziecka, w praktyce rozwodowej nierzadko generuje poważne trudności zarówno dla małżonków konstruujących plan, jak i sądu oceniającego jego treść, a w przypadku braku inicjatywy rodziców podejmującego władcze rozstrzygnięcie w przedmiocie zabezpieczenia interesu małoletniego.

W pewnym uproszczeniu można przyjąć, że porozumienie małżonków stanowi próbę interpretacji pojęcia interesu małoletniego z uwzględnieniem możliwie wielu płaszczyzn jego funkcjonowania. Klauzula dobra dziecka jest przy tym rozumiana jako kryterium dopuszczalności proponowanych przez rodziców rozstrzygnięć, jak również jako finalny rezultat, który ma zostać zrealizowany wskutek wykonywania postanowień planu. Przy ocenie skuteczności analizowanej instytucji należy wskazać na skutki w sferze teoretycznej i praktycznej. W odniesieniu do

33 Postanowienie Sądu Najwyższego z dnia 1 grudnia 2000 r., V CKN 1747/00. 
pierwszej z perspektyw samo wprowadzenie do polskiego prawa rodzinnego mechanizmu zabezpieczającego interes małoletniego na drodze współdziałania stron sporu należy uznać za korzystne. Stanowisko takie potwierdzają przedstawiciele doktryny, wskazując, że przed nowelizacją kodeksu prawo nie zapewniało pełnej ochrony dziecka przed skutkami rozwodu i towarzyszącego mu konfliktu małżonków ${ }^{34}$. Uchwalone zmiany dookreśliły problematykę sposobów sprawowania władzy rodzicielskiej i kontaktów z dzieckiem, jednak z uwagi na odrzucenie koncepcji domkniętego zbioru elementów składowych ${ }^{35}$ porozumienia nie zdołały wyeliminować wszystkich nieścisłości interpretacyjnych ${ }^{36}$. Zarzut terminologicznego i proceduralnego nieuporządkowania przynajmniej częściowo łagodzi argument wskazujący na możliwość optymalizacji interesu małoletniego. Należy zarazem podkreślić, że rozwiązanie postulowane w perspektywie teoretycznej, po włączeniu w sferę praktyki nie zawsze przynosi oczekiwane korzyści. Aktualne przepisy niewątpliwie sprzyjają rodzicom posiadającym merytoryczne przygotowanie z zakresu pedagogiki i psychologii, wykazującym konstruktywne nastawienie do sporu na tle rozwodowym ${ }^{37}$ oraz gotowym do szczegółowego zaplanowania przyszłej sytuacji życiowej dziecka

34 Zob. W. Stojanowska, Postulat przeniesienia koncepcji..., dz. cyt., s. 10.

35 W warstwie treściowej i proceduralnej, jak również w odniesieniu do wywoływanych skutków prawnych.

36 Brak normatywnego dopracowania instytucji porozumienia małżonków skutkuje, między innymi, trudnościami w określeniu właściwości sądów rejonowych i okręgowych do prowadzenia spraw rodzinnych, problemem $\mathrm{w}$ rozstrzygnięciu zagadnienia obligatoryjności porozumienia, czy niemożnością kontroli stopnia realizacji planu po zakończeniu postępowania rozwodowego. Zob. K. Gromek, Komentarz do artykułu 58 KRO, dz. cyt.

37 Na temat wpływu postawy rozwodzących się małżonków na optymalizację sytuacji dziecka w kontekście instytucji planu wychowawczego zob. A. Łopatkiewicz, Klauzula generalna dobra dziecka..., dz. cyt., s. 154nn. 
w zgodzie z abstrakcyjną, wymagającą wykładni klauzulą dobra małoletniego. Wskazane złożenie czynników determinujących nie tylko finalny kształt porozumienia, ale samą możliwość jego powstania, wydaje się przypadkiem nieporównywalnie rzadszym niż towarzysząca postępowaniu rozwodowemu atmosfera konfliktu i walki o dziecko. W rezultacie regulacja ukierunkowana na ochronę osoby dziecka w drodze koncyliacyjnego porozumienia małżonków okazuje się znacząco komplikować i tak trudną i złożoną sytuację rozwodu i związaną z nią konieczność reorganizacji dotychczasowego modelu funkcjonowania rodziny.

\section{Problematyka niedozwolonych postanowień umownych}

Instytucja niedozwolonych klauzul umownych ustanowiona została przepisami kodeksu cywilnego w celu regulacji stosunków prawnych pomiędzy konsumentem ${ }^{38}$ i przedsiębiorcą ${ }^{39}$. Z racji nierównoważnej pozycji wskazanych podmiotów w obrocie prawnym ${ }^{40}$ ustawodawca zabezpieczył interesy słabszej ze stron, stanowiąc, że postanowienia umowy zawartej z konsumentem nieuzgodnione indywidualnie nie wiążą go, jeśli kształtują jego prawa i obowiązki w sposób sprzeczny z dobrymi obyczajami, rażąco narusza-

38 Pod pojęciem konsumenta rozumieć należy osobę fizyczną dokonującą czynności prawnej niezwiązanej bezpośrednio z jej działalnością gospodarczą lub zawodową. Zob. art. $22^{1}$ k.c.

39 Za przedsiębiorcę uważa się osobę fizyczną, osobę prawną lub jednostkę niebędącą osobą prawną, ale posiadającą zdolność prawną, która prowadzi we własnym imieniu działalność gospodarczą lub zawodową. Zob. art. $43^{1}$ k.c.

40 Regulacja zawarta na gruncie polskiego systemu prawa prywatnego odzwierciedla europejski trend prawnej ochrony pozycji słabszego uczestnika obrotu prawnego w stosunkach prawnych z profesjonalistami. Zob. Dyrektywa Rady 93/13/EWG z dnia 5 kwietnia 1993 r. w sprawie nieuczciwych warunków w umowach konsumenckich. 
jąc jego interesy ${ }^{41}$. W przypadku kumulatywnego spełnienia wskazanych w treści przepisu przesłanek niedozwolone postanowienie przestaje wiązać strony stosunku prawnego. Podkreślenia wymaga, że pozostałe regulacje umowy pozostają w mocy, co oznacza, że przedmiotowa instytucja ukierunkowana jest na eliminację wadliwych elementów umowy, nie zaś na ustalenie jej nieważności.

Nierówności w relacji konsumenta względem przedsiębiorcy upatrywać można, w szczególności, w okazjonalnym charakterze czynności prawnych podejmowanych przez pierwszy z podmiotów i domniemany w związku z tym niższy zasób wiedzy z zakresu prawa w stosunku do strony trudniącej się profesjonalną działalnością gospodarczą lub zawodową ${ }^{42}$. Dysproporcję pomiędzy stronami ma wyważyć wprowadzenie do systemu prawa cywilnego reguły wykluczającej abuzywne, niekorzystne dla konsumenta postanowienia. Oprócz przesłanki podmiotowej, warunkiem możliwości skutecznego zastosowania przytoczonej regulacji jest włączenie do umowy postanowień nieuzgodnionych indywidualnie z konsumentem. Pod pojęciem tym należy rozumieć rozstrzygnięcia, na których treść konsument nie miał rzeczywistego wpływu ${ }^{43}$, a które łącznie spełniają przesłankę naruszenia dobrych obyczajów ${ }^{44}$ i rażącego pogwałcenia szeroko rozumianego interesu konsumenta, obejmujące, poza szkodą ekonomiczną, czynniki takie jak strata czasu czy przeszkody o charakterze organizacyjnym ${ }^{45}$.

${ }^{41}$ Art. $385^{1} \$ 1$ k.c. Wyjątek od wskazanej reguły stanowią postanowienia określające główne świadczenia stron, o ile zostały sformułowane w sposób jednoznaczny.

42 Zob. Kodeks cywilny. Komentarz, red. E. Gniewek, P. Machnikowski, Warszawa 2013, s. 56.

43 Więcej na temat postanowień nieuzgodnionych indywidualnie zob. K. Pietrzykowski, Komentarz do art. 385', Legalis, Warszawa 2013.

44 Zob. tamże.

45 Zob. tamże. Por. Kodeks cywilny. Komentarz, dz. cyt., s. 644. 
Instytucja klauzul abuzywnych wydaje się stanowić skuteczną przeciwwagę dla nieuczciwych praktyk profesjonalistów występujących w obrocie prawnym. Kodeksowa dopuszczalność wyłączenia niedozwolonych elementów składowych wzorca umownego stanowi warunek nieodzowny, ale zarazem niewystarczający do zapewnienia realnej ochrony interesu konsumenta. Regulację dopełnia system kontroli postanowień umownych, wzmacniający pozycję słabszego uczestnika stosunku prawnego. Prawo cywilne przewiduje dwa komplementarne modele kontroli - incydentalny i abstrakcyjny. W odniesieniu do pierwszego typu badanie obejmuje treść konkretnej umo$\mathrm{wy}^{46}$, której postanowienia nie podlegały indywidualnemu uzgodnieniu z udziałem konsumenta. Czynności kontrolne mogą zostać podjęte w ramach postępowania rozstrzygającego spór powstały uprzednio pomiędzy stronami umowy, lub na wniosek konsumenta, w celu uzyskania sądowego stwierdzenia bezskuteczności kwestionowanych klauzul ${ }^{47}$. Podkreślenia wymaga, że sądowa kontrola postanowień umownych pod kątem ich potencjalnej abuzywności wywołuje skutki prawne obejmujące wyłącznie strony badanego stosunku prawnego. Odmienna sytuacja ma miejsce w przypadku kontroli abstrakcyjnej, której przesłanką podjęcia jest sam fakt istnienia w obrocie wzorca umownego o wątpliwej skuteczności prawnej, bez konieczności zawierania umowy z jego zastosowaniem ${ }^{48}$. Kryterium oceny sądu stanowi zgodność wzorca z dobrymi obyczajami, które, jako klauzula generalna ${ }^{49}$, wymaga doprecyzowania

46 W sytuacji, w której doszło już do jej zawarcia.

47 Zob. M. Bednarek, Wzorce umów, [w:] System prawa prywatnego. Prawo zobowiązań - część ogólna, red. E. Łętowska, Warszawa 2013, s. 791.

48 Fakt zawarcia umowy nie wyłącza możliwości przeprowadzenia kontroli o charakterze abstrakcyjnym. Zob. tamże, s. 794.

49 Na temat interpretacji dobrych obyczajów na gruncie instytucji niedozwolonych postanowień umownych zob. tamże, s. 765nn. 
i odniesienia do elementów o charakterze niewyłącznie prawnym $^{50}$. Przeciwnie do instytucji kontroli incydentalnej, abstrakcyjna ocena postanowień umownych służyć ma nie tyle uzyskaniu orzeczenia o bezskuteczności klauzul w odniesieniu do konkretnego stosunku prawnego i określonych indywidualnie podmiotów, ile generalnemu zabezpieczeniu interesu wszystkich konsumentów poprzez niedopuszczenie do stosowania abuzywnego wzorca umownego w obrocie prawnym.

Dla realizacji funkcji, jaką spełniać ma abstrakcyjna kontrola sądowa, w roku 2000 powołano rejestr postanowień wzorców umowy uznanych za niedozwolone ${ }^{51}$. Katalog ten, obok danych dotyczących wyroku i stron, wskazuje konkretne postanowienie umowy uznane za niedozwolone prawomocnym orzeczeniem sądu właściwego do rozpoznania danej sprawy ${ }^{52}$. Pomimo faktu, że klauzula została uznana za abuzywną ${ }^{53} \mathrm{w}$ ramach stosunku prawnego pomiędzy indywidualnie określonymi podmiotami, jej treść wykracza poza wymiar incydentalny i z momentem wpisu nabiera ważności erga omnes, obejmując wszystkie stosunki prawne łączące konsumenta i przedsiębiorcę ${ }^{54}$. Rozszerzoną skuteczność omawianej instytucji potwierdza stanowisko Sądu Apelacyjnego w Warszawie, zgodnie z którym „prowadzenie przez Prezesa UOKiK ${ }^{55}$ jawnego rejestru

50 Zwłaszcza aksjologicznych. Zob. Kodeks cywilny. Komentarz, dz. cyt., s. 644.

51 Zob. Ustawa z dnia 17 listopada 1964 r. Kodeks postępowania cywilnego (T.j. Dz.U. z 2014 r., poz. 101 ze zm.), art. $479^{45}$ (dalej: k.p.c).

52 Na temat szczegółowego wzoru rejestru zob. Rozporządzenie Rady Ministrów z dnia 19 lipca 2000 r. w sprawie wzoru rejestru postanowień wzorców umowy uznanych za niedozwolone (Dz.U. z 2000 r. Nr 62, poz. 723).

53 Zarówno w następstwie zawartej umowy, jak i wniosku konsumenta o przeprowadzenie kontroli postanowienia umowy jeszcze niezawartej.

54 I spełniające przesłanki przedmiotowe wyrażone w art. $385^{1}$ i $385^{2}$ k.c.

55 Prezesa Urzędu Ochrony Konkurencji i Konsumentów. 
klauzul abuzywnych musi mieć głębszy sens, wykraczający poza działalność podmiotu, przeciwko któremu toczyło się postępowanie o uznanie postanowień wzorca umowy za niedozwolone. Celem prowadzenia rejestru jest bowiem wyeliminowanie niedozwolonych postanowień z obrotu, zaś kontrola postanowień, prowadząca do wpisu do rejestru ma charakter abstrakcyjny" ${ }^{56}$. Jawność katalogu oznacza, że jest on dostępny dla każdego zainteresowanego podmiotu ${ }^{57}$. Wskutek zapewnienia powszechnego dostępu do katalogu i regularnej aktualizacji jego zawartości, przy formułowaniu treści umowy lub korzystaniu z gotowego wzorca przedsiębiorca nie może zasłaniać się niewiedzą w kwestii postanowień uznanych za niedozwolone. W rezultacie wskazane rozwiązanie ma zabezpieczać treść konkretnych umów przed powielaniem uznanych sądownie za niedozwolone postanowień naruszających uzasadniony interes konsumenta.

Instytucja niedozwolonych klauzul umownych funkcjonująca na gruncie polskiego prawa prywatnego stanowi, przynajmniej w zamierzeniu ${ }^{58}$, przykład zagwarantowania prawnych instrumentów ochrony konsumenta legitymującego się niższym, w stosunku do przedsiębiorcy, doświadczeniem $\mathrm{w}$ obrocie prawnym. Incydentalna ocena treści umowy, niewątpliwie przydatna $\mathrm{z}$ punktu widzenia stron konkretnego sporu, wydaje się stanowić charakterystyczny dla demokratycznego państwa prawa przejaw

56 Wyrok Sądu Apelacyjnego w Warszawie z dnia 2 grudnia 2005 r., VI ACa 760/05.

57 Rejestr dostępny jest pod adresem internetowym www.uokik.gov.pl/ rejestr/ (06.10.2014).

58 Pomimo konstrukcji sugerującej wysoką praktyczną skuteczność, instytucja niedozwolonych postanowień umownych nie jest wolna od nieścisłości dotyczących wykładni odnośnych przepisów k.c. i k.p.c., jak również relacji krajowego porządku prawnego względem ustawodawstwa unijnego. Zob. R. Trzaskowski, M. Wild, Kontrola abstrakcyjna wzorców umów w świetle badań sądowych, Instytut Wymiaru Sprawiedliwości, Warszawa 2012. 
zagwarantowania możliwości sądowego dochodzenia swoich racji. Szczególnie interesująca wydaje się kontrola w wymiarze abstrakcyjnym oraz powiązany z nią rejestr niedozwolonych postanowień umownych. Osobliwość analizowanego mechanizmu polega na skatalogowaniu niekorzystnych doświadczeń poszczególnych podmiotów prawa w ramach systemu zabezpieczającego teraźniejszy, jak również przyszły interes każdego konsumenta zawierającego umowę z przedsiębiorcą. Kolejna nowelizacja rejestru prowadzi do abstrakcyjnej eliminacji z przestrzeni prawnej postanowień niedozwolonych, poszerzając tym samym zakres prawnej ochrony konsumenta. Rozwiązanie takie nie generuje przy tym konieczności podejmowania przez konsumenta jakichkolwiek działań mających na celu zaktualizowanie ciążącego na przedsiębiorcy obowiązku ukształtowania treści umowy w zgodzie z obowiązującym stanem prawnym. Bieżąca archiwizacja przypadków indywidualnych nadużyć chroni osłabioną pozycję konsumenta w stosunkach z profesjonalistą oraz zabezpiecza płynność obrotu prawnego.

\section{Model planu wychowawczego w kontekście instytucji niedozwolonych postanowień umownych}

Z racji zasadniczych różnic obejmujących zarówno prawnomaterialną, jak i proceduralną charakterystykę porozumienia małżonków z jednej strony i systemu niedozwolonych postanowień umownych z drugiej, regulacji tych nie sposób odnieść względem siebie wprost. W warstwie podmiotowej strony postępowania rozwodowego cechuje, co do zasady, zbliżona sytuacja prawna oraz porównywalny zakres wiedzy i doświadczenia w zakresie sprawowania władzy rodzicielskiej. W przypadku modelu klauzul abuzywnych, pomiędzy konsumentem i przedsiębiorcą 
występuje zazwyczaj dysproporcja w zakresie znajomości prawa, skutkująca wyjściową, słabszą pozycją pierwszego z podmiotów. W odniesieniu do sfery przedmiotowej radykalnie odmiennie kształtuje się przesłanka, dla której analizowane instytucje znajdują zastosowanie. Porozumienie małżonków ukierunkowane jest na dobro wspólnego, małoletniego dziecka, podczas gdy umowa zawarta pomiędzy uczestnikami obrotu prawnego ma na celu realizację interesów o charakterze ekonomicznym. Jakkolwiek obie instytucje pośrednio lub bezpośrednio kształtują prawa i obowiązki, ich zakres oraz generowane skutki prawne znacząco się różnią. Zarazem, pomimo niemożności skonstruowania bezpośredniej analogii ${ }^{59}$ pomiędzy wskazanymi regulacjami, nie można wykluczyć poszukiwania rozwiązań, które, pod warunkiem odpowiedniej generalizacji i adaptacji, można zastosować do optymalizacji innych instytucji prawa prywatnego. Proponowana analogia sui generis polega na wyodrębnieniu z problematyki niedozwolonych postanowień umownych tych instrumentów prawnych, które, po niezbędnej modyfikacji, można odnieść do zagadnienia porozumienia małżonków w celu wsparcia rodziców w projektowaniu przyszłej sytuacji dziecka.

Spośród rozwiązań prawnych regulujących problematykę niedozwolonych klauzul umownych tylko niektóre wydają się potencjalnie przydatne $\mathrm{z}$ uwagi na instytucję planów wychowawczych. W szczególności należy pominąć, jako redundantny, wątek incydentalnej kontroli sądowej, który w przypadku postępowania rozwodowego występuje obligatoryjnie na etapie sądowej oceny zgodności przedłożonego przez strony porozumienia z dobrem dziecka lub, w przypadku braku planu, w postaci władczego rozstrzygnięcia o sposobie sprawowania władzy rodzicielskiej

$59 \quad \mathrm{Na}$ temat analogii w odniesieniu do norm prawa zob. zamiast wielu starszych prac M. Walasik, Analogia w prawie procesowym cywilnym, Warszawa 2013, s. 175nn. 
i kontaktach z małoletnim. Podobnie zastosowania nie znajduje dyspozycja, na mocy której postanowienie umowne o charakterze abuzywnym ${ }^{60}$ nie wiąże strony, do której jest adresowane. Proste przeniesienie wskazanego mechanizmu do instytucji porozumienia małżonków byłoby niespójne z koniecznością sądowego zatwierdzenia treści planu, co więcej, wymagałoby wyczerpującej operacjonalizacji klauzuli generalnej dobra dziecka. Należy też pamiętać, że zasada swobody umów pozostawiająca konsumentowi i przedsiębiorcy dużą dozę luzu decyzyjnego w kształtowaniu wzajemnych praw i obowiązków nie może zostać uznana za zakresowo tożsamą z uprawnieniem rodziców do zaplanowania funkcjonowania dziecka po orzeczeniu rozwodu.

Podstawowa trudność w implementacji mechanizmów regulujących problematykę niedozwolonych postanowien umownych w zakres rozważań poświęconych planowi wychowawczemu wynika z wprowadzenia do systemu prawa rodzinnego klauzuli generalnej dobra dziecka. O ile model regulujący zawieranie umów cywilnych również oparty został na klauzuli generalnej - dobrych obyczajów - stanowiącej jedną z przesłanek umożliwiających stwierdzenie bezskuteczności niedozwolonego postanowienia, o tyle w przypadku stosunków prawnych łączących konsumenta i przedsiębiorcę pojęcie to posiada węższy zakres znaczeniowy i podlega prostszej operacjonalizacji, niż ma to miejsce w przypadku kategorii dobra dziecka. Pomimo lapidarnego ujęcia przepisów prawa rodzinnego skoncentrowanych na osobie dziecka w kontekście rozwodu, sugerującego możliwość ich względnie szerokiej interpretacji, z uwagi na szczególny, aksjologiczny wymiar regulacje te podlegają szczegółowej kontroli sądu. Mając zarazem na uwadze zróżnicowanie potrzeb dziecka na różnych etapach

60 Przy spełnieniu stosownych przesłanek i z wyłączeniem wyjątków wskazanych w treści art. $385^{1}$ k.c. 
jego rozwoju, nie sposób postulować utworzenia naśladującego rejestr klauzul abuzywnych zbioru twierdzeń jednoznacznie rozstrzygających kwestię dobra dziecka, a przy tym uwzględniających jego rzeczywistą, niepowtarzalną sytuację życiową.

Brak bezpośredniej przekładalności przedmiotowych instytucji nie wyklucza prób poszukiwania odpowiedniości na poziomie poszczególnych rozwiązań legislacyjnych regulujących problematykę niedozwolonych postanowień umownych i planów wychowawczych. Spośród mechanizmów stosowanych w ramach modelu klauzul abuzywnych i możliwych do przetransponowania na grunt instytucji porozumienia małżonków na szczególną uwagę zasługuje zagadnienie abstrakcyjnej kontroli sądowej oraz powiązany z nim rejestr niedozwolonych postanowień umownych. Chociaż regulacji tych nie sposób przenieść bezpośrednio do kontekstu postępowania rozwodowego, mogą one stanowić inspirację dla tworzenia rejestru o innych funkcjach i skutkach prawnych. Walor wynikający z gromadzenia przypadków naruszenia interesu jednej ze stron stosunku prawnego $\mathrm{w}$ celu wyeliminowania $\mathrm{z}$ obrotu rażąco niekorzystnych unormowań z powodzeniem, z zastrzeżeniem koniecznych modyfikacji, można wykorzystać $\mathrm{w}$ postępowaniu rozwodowym na etapie tworzenia planów wychowawczych i oceny ich zgodności z klauzulą dobra dziecka. Można prognozować, że włączenie mechanizmu kontroli na poziomie abstrakcyjnym, dopełnione sui generis $^{61}$ rejestrem klauzul naruszających interes dziecka, mogłoby wspomóc wypracowanie efektywnego rozstrzygnięcia w przedmiocie sytuacji życiowej małoletniego po

${ }^{61}$ Z racji braku skuteczności erga omnes sprzeczność ustaleń z kategorią dobra dziecka należy oceniać kontekstowo. Z tego względu, w przypadku praktycznej implementacji nazwę rejestru należałoby uzupełnić o wzmiankę sugerującą jedynie prawdopodobieństwo niezgodności z klauzulą generalną. 
orzeczeniu rozwodu, a ponadto umożliwić realizację funkcji porozumienia postulowanych przez przedstawicieli doktryny, a dotychczas raczej słabo realizowanych w praktyce sądowej ${ }^{62}$.

Pewne podobieństwo pomiędzy analizowanymi instytucjami zaznacza się już w warstwie podmiotowej. Odpowiednikiem konsumenta zajmującego co do zasady mniej korzystną sytuację niż przedsiębiorca są na gruncie prawa rodzinnego małżonkowie będący stronami postępowania rozwodowego. Należy przy tym założyć, że zakres ich wiedzy i doświadczenia jest raczej porównywalny, co skłania do uznania podobnej wyjściowej pozycji stron względem $s_{a ̨ d}{ }^{63}$. Brak specjalistycznych kompetencji z zakresu psychologii i pedagogiki z całą pewnością należy uznać za okoliczność utrudniającą konstrukcję wyczerpującego, zgodnego z klauzulą dobra dziecka planu. Szanse na wypracowanie satysfakcjonującego porozumienia komplikuje ponadto angażująca emocje atmosfera konfliktu niesprzyjająca obiektywizacji sytuacji i potrzeb dziecka. Zarazem jednak, w realizacji celu, jakim jest sporządzenie porozumienia w zgodzie z klauzulą generalną dobra dziecka,

62 W krytycznej opinii niektórych przedstawicieli doktryny nowela k.r.o. w materii związanej z zabezpieczeniem sytuacji małoletniego po orzeczeniu rozwodu wprowadza zapis o charakterze blankietowym, w obecnym kształcie prawnym pozostający bez wpływu na przestrzeganie klauzuli dobra dziecka. Zob. K. Gromek, Komentarz do artykutu $58 \mathrm{KRO}$, dz. cyt.

63 Na gruncie doktryny podnosi się niekiedy zarzut uprzywilejowanego traktowania kobiety będącej stroną postępowania i jej faworyzowania w kwestii ustaleń dotyczących sprawowania władzy rodzicielskiej i utrzymywania kontaktów z dzieckiem. Z punktu widzenia przepisów regulujących problematykę opieki nad dzieckiem po orzeczeniu rozwodu, to dobro małoletniego, a nie płeć rodzica stanowi uzasadnienie dla podjętych decyzji. Uchybienia sądów w tym względzie należy zatem traktować jako możliwe, incydentalne naruszenie klauzuli dobra dziecka, nie zaś jako wyraźną tendencję orzeczniczą, dającą podstawę do przyjęcia innych, pozakodeksowych przesłanek o zbliżonej doniosłości prawnej. 
małżonkowie przyjmują rolę zbliżoną do tej, jaką w obrocie prawnym pełni przedsiębiorca. Przypomnieć należy, że współdziałanie rodziców oraz przedłożenie porozumienia traktowane są jako przesłanki sine qua non możliwości zachowania przez oboje małżonków pełnej władzy rodzicielskiej. Regulacja ta, jakkolwiek potencjalnie korzystna dla funkcjonowania dziecka po rozwodzie, nakłada na strony postępowania oczekiwanie przyjęcia odpowiedzialnego i profesjonalnego nastawienia, co, wziąwszy pod uwagę kryzysowy charakter rozwodu, uznać należy za sytuację trudną. Wsparcie w postaci systemu monitorującego przykłady braku zgodności elementów składowych porozumienia z kryterium interesu małoletniego wydaje się korzystne z zarówno uwagi na optymalizację przebiegu tworzenia planu, jak również rezultat determinujący przyszłą sytuację dziecka.

Drugim z elementów charakterystycznych dla analizowanych instytucji jest ich oparcie na klauzulach generalnych. W przypadku systemu niedozwolonych postanowień umownych kryterium dobrych obyczajów wyznacza zarazem warunek stwierdzenia abuzywności w przypadku jego naruszenia, jak również cel prowadzenia rejestru polegający na eliminacji z obrotu prawnego elementów rażąco naruszających interes jednej ze stron. W przypadku instytucji porozumienia małżonków klauzula dobra dziecka ma zabezpieczać funkcjonowanie dziecka przed następstwami rozpadu dotychczasowego modelu rodziny. Podobnie dobro dziecka uznać można zarazem za warunek przystąpienia rodziców do konstrukcji planu wychowawczego ${ }^{64}$, jak i finalny efekt w postaci zabezpieczenia funkcjonowania małoletniego. W obu przypadkach klauzule wymagają każdorazowej oceny uwzględniającej kryteria niewyłącznie

64 W obowiązującym stanie prawnym rozwód nie jest dopuszczalny, jeśli w jego następstwie miałoby dojść do naruszenia klauzuli dobra dziecka. Zob. art. $56 \$ 2$ k.r.o. 
prawne, przy czym z uwagi na złożoność przedmiotową i temporalną, jak również zasadę indywidualizacji, kategoria dobra dziecka nie podlega pełnej operacjonalizacji, co nie wyklucza, rzecz jasna, zasadności podejmowania prób precyzowania tego pojęcia.

Przeniesienie rozwiązań stosowanych w systemie klauzul abuzywnych do instytucji porozumienia małżonków skutkowałoby wprowadzeniem mechanizmu abstrakcyjnej kontroli sądowej treści planów wychowawczych pod kątem ich zgodności z klauzulą dobra dziecka oraz stworzeniem rejestru dokumentującego te spośród ustaleń, które, sprzeczne $\mathrm{z}$ interesem dziecka $\mathrm{w}$ konkretnym przypadku, $\mathrm{z}$ wysokim prawdopodobieństwem można by uznać za niedopuszczalne w większej liczbie przypadków. Analogicznie zadanie kontroli porozumień małżonków należałoby scedować na sądy rozpatrujące sprawy o rozwód. Podkreślenia wymaga, że nowa dyspozycja nie wymagałaby ani istotnych nakładów ekonomicznych, ani znacznej ilości dodatkowego czasu. Skoro w ramach każdego postępowania rozwodowego sąd zobligowany jest do zbadania zgodności porozumienia z dobrem konkretnego dziecka, co utożsamić można z mechanizmem kontroli incydentalnej, wyodrębnienie elementów niezgodnych z klauzulą i ich opracowanie celem włączenia do rejestru należy uznać za aktywność niezbyt pracochłonną, a przy tym potencjalnie wysoce przydatną. Równolegle do sądowej oceny treści porozumienia, wniosek o ocenę zgodności z dobrem dziecka poszczególnych rozstrzygnięć mógłby wnosić każdy z małżonków już na etapie przygotowania planu. Regulacja taka, poza bieżącą weryfikacją normatywnego wymiaru porozumienia, prawdopodobnie przyczyniłaby się również do realizacji postulowanej przez doktrynę funkcji edukacyjnej i prewencyjnej.

Pod względem struktury kryteria stosowane w rejestrze klauzul abuzywnych wydają się w dużej mierze adekwatne także w przypadku instytucji porozumienia małżonków. 
$\mathrm{Z}$ uwagi na cel, jakim jest sugerowanie eliminacji $\mathrm{z}$ treści planów wychowawczych ustaleń z dużym prawdopodobieństwem sprzecznych z interesem dziecka, użyteczną modyfikacją byłoby zastąpienie wymogu wyszczególnienia w rejestrze sygnatury sprawy i oznaczenia stron opisem sytuacji dziecka, którego porozumienie dotyczy. Skrótowa charakterystyka małoletniego ze szczególnym uwzględnieniem jego wieku, kondycji rodziny sprzed rozwodu, projektowanego modelu jej funkcjonowania po zakończeniu postępowania i innych treści istotnych $\mathrm{z}$ uwagi na kształt porozumienia należy uznać za istotne źródło informacji, zwłaszcza dla stron postępowania rozwodowego znajdujących się w podobnym położeniu. Kontekstowe osadzenie rozstrzygnięcia uznanego przez sąd za niezgodne z dobrem dziecka może służyć za wskazówkę interpretacyjną, pomocną przy operacjonalizacji interesu małoletniego w ramach kolejnych spraw rozwodowych ${ }^{65}$. Pomimo faktu, że klauzula generalna wymaga każdorazowego odniesienia do sytuacji konkretnego dziecka i jako taka podlega jedynie fragmentarycznej interpretacji ${ }^{66}$, katalog twierdzeń konstruujący negatywną definicję dobra dziecka wydaje się stanowić wartościowe poznawczo kryterium wskazujące, jakich ustaleń z dużą dozą prawdopodobieństwa podejmować nie należy, mając na uwadze interes własnego dziecka.

Organem prowadzącym rejestr niedozwolonych postanowień umownych jest Prezes Urzędu Ochrony Konkurencji i Konsumentów ${ }^{67}$. Jest on centralnym organem administracji rządowej, a jego właściwość obejmuje sprawy

65 Por. M. Araszkiewicz, A. Łopatkiewicz, A. Zienkiewicz, Factors and Dimensions in the Parent Plan Support System, [w:] Transparenz. Tagungsband des 17. Internationalen Rechtsinformatik Symposions IRIS 2014, ed. E. Schweighofer, F. Kummer, W. Hötzendorfer, Wien 2014.

66 I która, jak trafnie pokazują próby opisu podejmowane na gruncie orzecznictwa, wykorzystuje terminy o równie wysokim stopniu ogólności.

67 Ustawa z dnia 16 lutego 2007 r. o ochronie konkurencji i konsumentów (Dz.U. z 2007 r. Nr 50, poz. 331 ze zm.), art. 29nn. 
związane z ochroną interesów konsumentów oraz kształtowaniem polityki antymonopolowej. Problematyka klauzul abuzywnych stosowanych w umowach zawieranych pomiędzy konsumentem i przedsiębiorcą niewątpliwie wpisuje się z zakres działalności Urzędu. W przypadku postanowień małżonków regulujących sytuację życiową dziecka w sposób sprzeczny z kryterium jego dobra, organem właściwym do prowadzenia rejestru wydaje się być instytucja prowadząca politykę rodzinną lub koncentrująca swoją aktywność wokół osoby dziecka. Stylistyka regulacji poświęconej porozumieniu małżonków w sposób jednoznaczny wskazuje na dobro dziecka, a nie całej rodziny jako przesłankę oceny treści planu, co sugeruje, że odpowiedni do spraw rejestru byłby raczej organ stojący na straży praw dziecka. W obowiązującym stanie prawnym funkcję taką pełni Rzecznik Praw Dziecka. Co szczególnie znaczące, ustawa ${ }^{68}$ regulująca kompetencje Rzecznika stanowi, że przy wykonywaniu uprawnień kieruje się on dobrem dziecka, zaś rodzinę ujmuje jako naturalne środowisko rozwoju młodego człowieka ${ }^{69}$. Bezspornie, w ramach działalności mającej na celu zapewnienie dziecku pełnego i harmonijnego rozwoju $\mathrm{u}^{70}$ oraz ochronę przed zaniedbaniem i nieodpowiednim traktowaniem ${ }^{71}$, mieści się postulat zabezpieczenia sytuacji dziecka przed niekorzystnymi skutkami rozwodu i rozpadu dotychczasowego modelu funkcjonowania rodziny. Rzecznik jako gwarant przestrzegania prawa dziecka wydaje się być zatem organem najwłaściwszym do prowadzenia rejestru dokumentującego przypadki naruszeń klauzuli interesu małoletniego przy konstrukcji planów wychowawczych.

68 Ustawa z dnia 6 stycznia 2000 r. o Rzeczniku Praw Dziecka (Dz.U. z 2000 r. Nr 6, poz. 69).

69 Zob. tamże, art. 1 ust. 3.

70 Zob. tamże, art. 3 ust. 1.

71 Zob. tamże, art. 3 ust. 3. 
Analizę instytucji porozumienia małżonków w kontekście abstrakcyjnej kontroli sądowej i rejestru postanowień niezgodnych z klauzulą dobra dziecka należy dopełnić oceną przydatności proponowanych rozwiązań dla poszczególnych podmiotów bezpośrednio i pośrednio uczestniczących w procedurze rozwodowej. O ile system klauzul abuzywnych skonstruowany został w celu zabezpieczenia interesu dokładnie jednej strony stosunku prawnego - konsumenta - o tyle w przypadku zagadnienia planów wychowawczych jednoznaczne wskazanie adresata nie jest równie oczywiste. Obok małżonków będących stronami sporu, w postępowaniu rozwodowym udział bierze sąd oraz, incydentalnie, organizacje o profilu konsultacyjnym i mediacyjnym. Poza podmiotami uczestniczącymi w sprawie, do grona potencjalnych beneficjentów postulowanych zmian należy zaliczyć dziecko, którego sytuacja życiowa uzależniona jest od ustaleń zawartych w planie wychowawczym oraz ich prawidłowej realizacji.

Pozostawienie małżonkom ograniczonej kontrolą sądu autonomii w kwestii treści porozumienia skłania do przyjęcia, że to właśnie strony sporu należy uznać za adresatów systemu monitorującego uznane za sprzeczne z klauzulą dobra dziecka postanowienia planów wychowawczych. Z uwagi na trudności we współdziałaniu małżonków, brak odpowiedniego przygotowania pedagogicznego, psychologicznego i prawnego oraz niewielki udział instytucji doradczych, scedowane na małżonków zadanie zamiast optymalizować położenie małoletniego, stwarza ryzyko nadużyć w zakresie operacjonalizacji kategorii dobra. Rejestr zawierający informacje na temat sytuacji dziecka oraz postanowień wyłączonych z treści porozumienia rozstrzygnięciem sądu z całą pewnością należy uznać za przydatny zbiór wskazówek interpretacyjnych porządkujących strukturę planu oraz treść poszczególnych ustaleń. Jakkolwiek, przeciwnie do sytuacji konsumenta $\mathrm{w}$ modelu klauzul abuzywnych, skatalogowane niedozwolone postanowienia 
nie mogą zostać uznane za adekwatne do sytuacji każdego dziecka, nie umniejsza to poznawczego waloru wynikającego z możliwości korekty treści porozumienia w oparciu o doświadczenia innych rodziców.

Pomimo że strony sporu wydają się głównymi odbiorcami systemu abstrakcyjnej kontroli postanowień treści porozumienia, na funkcjonowaniu rejestru skorzystać mogą również inne podmioty zaangażowane $\mathrm{w}$ przebieg postępowania rozwodowego. W odniesieniu do organizacji świadczących profesjonalną pomoc doradczą i mediacyjną wprowadzenie postulowanych modyfikacji umożliwiałoby bieżącą weryfikację trudności napotykanych przez rodziców w związku z konstrukcją planu oraz trafniejsze dostosowanie oferowanej pomocy do faktycznego zapotrzebowania stron. W przypadku wymiaru sprawiedliwości możliwość związania sądu treścią rejestru wyklucza już sama niemożność sztywnego dookreślenia kategorii dobra dziecka. Ponadto stoi temu na przeszkodzie zasada niezawisłości i niezależności sędziowskiej. System monitorujący przypadki naruszenia klauzuli dobra dziecka należy zatem w przypadku sądów traktować jako opcjonalny zestaw wskazówek interpretacyjnych, których uwzględnienie, podobnie jak w przypadku orzecznictwa sądów i trybunałów, w kontynentalnej kulturze prawnej ma, co do zasady, walor perswazyjny i pomocniczy. W sytuacji, w której wskutek braku współdziałania małżonków lub stwierdzenia naruszenia interesu małoletniego sąd zobligowany jest do wydania orzeczenia w kwestii władzy rodzicielskiej i utrzymywania kontaktów z dzieckiem, rejestr może stanowić przydatne źródło informacji o postanowieniach uznanych, w ocenie innych sądów, za niedopuszczalne w konkretnych przypadkach. Wydaje się, że postulowany rejestr stanowi wartościowe uzupełnienie wskazówek dostarczanych przez sądy wyższych instancji. Jakkolwiek autorytet sądu powszechnego wydającego rozstrzygnięcie włączone do katalogu jest niższy niż ma to miejsce choćby w przypadku 
orzeczeń Sądu Najwyższego, liczba wszczynanych rokrocznie postępowań pozwala na zebranie niezwykle obszernego materiału poglądowego dostępnego dla sądów właściwych do spraw związanych z osobą dziecka, w tym innych niż tylko rozwodowe ${ }^{72}$.

Nie wprost, podstawowym beneficjentem postulowanych zmian legislacyjnych jest dziecko małżonków uczestniczących w postępowaniu rozwodowym. Wyłączne kryterium oceny treści porozumienia wyznacza zasada dobra małoletniego, która w toku przygotowania porozumienia oraz jego sądowej oceny i zatwierdzenia nie doznaje żadnych wyjątków. Nadrzędnym celem wprowadzenia do polskiego prawa rodzinnego instytucji planu wychowawczego było zabezpieczenie sytuacji dziecka przed niekorzystnymi skutkami rozwodu. Zarówno uznanie inicjatywy małżonków w wypracowaniu porozumienia względem sądowego rozstrzygnięcia, jak i postulowana abstrakcyjna kontrola postanowień wraz z rejestrem rozwiązań uznanych za niedopuszczalne w określonych stanach faktycznych mają służyć optymalizacji funkcjonowania dziecka. Każdy mechanizm wspomagający interpretację klauzuli generalnej i finalnie sprzyjający możliwie wielopłaszczyznowej regulacji sytuacji dziecka należy uznać za potencjalnie korzystny i z tej racji wart praktycznej implementacji.

Zabezpieczenie interesu dziecka poprzez unormowanie jego sytuacji po zakończeniu postępowania rozwodowego niewątpliwie należy uznać za podstawowy cel funkcjonowania instytucji porozumienia małżonków uwzględniającej proponowane zmiany legislacyjne. Pomimo trudności

72 Wymóg zgodności ustaleń poczynionych w sprawie dziecka z klauzulą jego dobra stanowi kryterium dla większej liczby regulacji z zakresu prawa rodzinnego i opiekuńczego. Można przypuszczać, że rejestr dokumentujący przypadki naruszeń interesu małoletniego okaże się podobnie przydatny w kwestiach związanych z władzą rodzicielską w kontekście innym niż rozwód, pieczą zastępczą czy przysposobieniem. 
w operacjonalizacji kategorii dobra dziecka, abstrakcyjna kontrola treści porozumienia oraz połączony z nią katalog klauzul niedozwolonych umożliwiają konstrukcję quasi-definicji negatywnej, złożonej z twierdzeń wskazujących, czym w danym stanie faktycznym dobro dziecka nie jest. Z funkcjonowania zbioru wskazówek interpretacyjnych mogą korzystać, w szczególności, strony postępowania rozwodowego. Możliwość bieżącej korekty treści porozumienia już na etapie jego tworzenia umożliwia eliminację postanowień sprzecznych z klauzulą dobra dziecka, co poza oczywistą konsekwencją w postaci optymalizacji położenia małoletniego zmniejsza ryzyko przewlekłości postępowania spowodowanej potrzebą rewizji postanowień i ich ponownej oceny przez sąd. Wydaje się, że poza zaletami o charakterze proceduralnym i organizacyjnym, modyfikacja instytucji planu wychowawczego wywiera wpływ na efektywność współpracy pomiędzy małżonkami. Postawa współdziałania stron, jakkolwiek niezbędna przy tworzeniu porozumienia, nie gwarantuje wypracowania satysfakcjonującego rozstrzygnięcia. Konieczność zaplanowania nowego modelu funkcjonowania rodziny stwarza trudność nawet najbardziej koncyliacyjnie nastawionym małżonkom. Zalecenia dedukowane $\mathrm{z}$ sentencji zgromadzonych w rejestrze sprzyjają koncentracji na klauzuli dobra dziecka, redukując tym samym prawdopodobieństwo ukształtowania treści planu w oparciu o inne kryteria. Co więcej, sam fakt funkcjonowania systemu można traktować jako dowód na rzecz tezy o wysokim stopniu komplikacji przedmiotowej warstwy porozumienia. Niepewność co do poszczególnych elementów planu przesądza nie tyle o braku odpowiednich kompetencji rodzicielskich, ile o obiektywnej trudności wynikającej z powierzonego stronom zadania. Świadomość możliwości błędnej operacjonalizacji pojęcia dobra dziecka przy równoczesnej sposobności do korekty treści porozumienia na każdym etapie jego tworzenia wydaje się, rów- 
nolegle do wspomnianej funkcji edukacyjnej i organizacyjnej, stanowić istotny czynnik optymalizujący proces konstrukcji planu.

Poprawa w zakresie zgodności postanowień porozumienia z klauzulą dobra dziecka posiada pewne przełożenie na usprawnienie przebiegu postępowania rozwodowego $\mathrm{w}$ aspekcie związanym $\mathrm{z}$ problematyką władzy rodzicielskiej. Podkreślenia wymaga, że im lepiej małżonkowie wywiązują się z zadania zaprojektowania funkcjonowania dziecka po orzeczeniu rozwodu, w tym mniejszym stopniu sąd zobowiązany jest ingerować w treść planu. Nawet najbardziej korzystny z uwagi na interes małoletniego zbiór ustaleń podlega, co prawda, sądowej kontroli zgodności z klauzulą generalną, jednak jej zakres należy ocenić jako znacznie węższy niż ma to miejsce w przypadku władczego sądowego rozstrzygnięcia o sytuacji małoletniego na skutek nieprzedstawiania porozumienia lub jego poważnej wadliwości. Zasadna wydaje się teza, zgodnie z którą dodatkowe, merytoryczne wsparcie zwiększa szanse na realizację modelu, w którym ustawodawca to rodzicom, a nie sądowi w pierwszej kolejności powierzył zabezpieczenie funkcjonowania dziecka, przy równoczesnej minimalizacji ryzyka przewlekłości postępowania z przyczyn leżących po stronie małżonków.

Poza potencjalną optymalizacją interesu małoletniego, wyposażeniem małżonków w zestaw wskazówek interpretacyjnych i prawdopodobnym odciążeniem sądu w funkcji projektowania sytuacji dziecka, wprowadzenie mechanizmu abstrakcyjnej kontroli treści porozumienia oraz rejestru niedozwolonych postanowień posiada istotny walor poznawczy. Jakkolwiek instytucja planów wychowawczych funkcjonuje na gruncie polskiego prawa rodzinnego już od ponad sześciu lat, $w$ dalszym ciągu generuje pewne wątpliwości interpretacyjne, związane z procedurą jej stosowania czy skutkami prawnymi. Co więcej, z uwagi na interdyscyplinarny charakter rozważań skoncentrowanych wokół 
osoby dziecka w kontekście rozwodu analizowana regulacja wykracza poza materię wyłącznie prawną, zyskując zainteresowanie nauk pedagogicznych, psychologicznych czy socjologicznych. Nie ulega wątpliwości, że rejestr gromadzący i aktualizujący przypadki rozwiązań godzących $\mathrm{w}$ kryterium interesu małoletniego stanowi obiekt wartościowy z punktu widzenia szeroko rozumianych nauk o rodzinie. Opracowanie problematyki oscylującej wokół kategorii dobra dziecka, władzy rodzicielskiej, możliwości zaplanowania całościowego modelu funkcjonowania rodziny czy wykonalności postanowień planu sprzyja aktualizacji wiedzy w wymiarze teoretycznym, zaś w sferze praktyki może służyć rewizji i udoskonaleniu dotychczasowych rozwiązań legislacyjnych i pomocowych.

\section{Uwagi końcowe}

Nawet najbardziej dopracowany zbiór przepisów nie jest w stanie uchronić małżonków i dziecka przed skomplikowanymi, emocjonalnymi następstwami załamania dotychczasowego modelu funkcjonowania rodziny. Jakkolwiek intencją ustawodawcy jest realizacja zasady interesu małoletniego w kluczowych płaszczyznach jego życia, orzeczenie sądu w kwestii sprawowania władzy rodzicielskiej jedynie w wymiarze formalnym i organizacyjnym reguluje złożoną sytuację podmiotów objętych skutkami rozwodu. Zarazem można przypuszczać, że konstruktywne podejście do problemu już na etapie postępowania rozwodowego sprzyja osiągnięciu postawy współdziałania po rozwiązaniu małżeństwa, co poza rękojmią realizacji ustaleń zawartych w planie, znacząco zwiększa szansę na pomyślną reorganizację sposobu funkcjonowania poszczególnych członków rodziny przy podtrzymaniu wzajemnych, pozytywnych relacji. Instytucja porozumienia małżonków o sposobie sprawowania 
władzy rodzicielskiej i utrzymywaniu kontaktów z dzieckiem z całą pewnością wpisuje się w trend ochrony dziecka przed niekorzystnymi skutkami rozwodu. Zarazem, w aktualnym stanie prawnym, regulacji nie sposób uznać za optymalną ani z uwagi na interes dziecka, ani małżonków, ani wymiaru sprawiedliwości. Pozostawienie rodzicom luzu decyzyjnego w kwestiach dotyczących dziecka bez równoczesnego wyposażenia ich w narzędzia usprawniające proces konstrukcji planu należy uznać za zjawisko raczej minimalizujące szanse na wypracowanie satysfakcjonującego dla wszystkich podmiotów rozstrzygnięcia. Obok niedopracowanych rozwiązań proceduralnych, istotne utrudnienie stanowi niemożność abstrakcyjnego wyznaczenia granic kategorii dobra dziecka i związana z nią konieczność każdorazowej indywidualizacji potrzeb dziecka oraz skorelowanych z nimi praw i obowiązków rodziców. Wydaje się, że realizacja celu leżącego u podstaw wprowadzenia do polskiego prawa rodzinnego instytucji porozumienia małżonków wymaga koniecznego wsparcia merytorycznego i proceduralnego. Propozycji usprawnienia procesu tworzenia planu oraz jego przedmiotowej trafności dostarcza system niedozwolonych postanowień umownych $\mathrm{z}$ powodzeniem stosowany $\mathrm{w}$ obrocie prawnym z udziałem konsumentów. Pomimo faktu, że włączenie wskazanej regulacji na drodze analogii sensu stricto nie jest możliwe, pewne elementy modelu znajdują zastosowanie na gruncie rozważań poświęconych postępowaniu rozwodowemu.

Należy jednoznacznie podkreślić, że implementacja idei abstrakcyjnej kontroli porozumienia oraz kontekstowego rejestru budzących wątpliwości postanowień w żadnym razie nie wyręcza małżonków w konieczności odniesienia klauzuli generalnej dobra do sytuacji ich dziecka. Rejestr, gromadząc doświadczenia rodziców związane z regulacją kwestii władzy rodzicielskiej, dostarcza jedynie wskazówek interpretacyjnych, które w mniejszym lub 
większym stopniu mogą wspomóc konstrukcję porozumienia. Zasadniczą przeszkodę w prostej analogii pomiędzy katalogiem niedozwolonych postanowień zawartych w umowach konsumenckich i planach wychowawczych można uznać zarazem za walor uniemożliwiający proste unikanie zawierania $\mathrm{w}$ planie dyspozycji umieszczonych $\mathrm{w}$ rejestrze bez uprzedniego zbadania rzeczywistych potrzeb dziecka. Obligatoryjna kontrola sądu poprzedzająca ewentualne zatwierdzenie treści porozumienia eliminuje możliwość zaprojektowania funkcjonowania małoletniego w sposób sprzeczny z przedmiotową klauzulą. Tym samym wykluczone zostaje ryzyko zniekształcania zawartości planu wskutek bezrefleksyjnego stosowania przez małżonków rozwiązań wprost przeciwstawnych tym, które umieszczono w rejestrze.

Pomimo że postulowane zmiany legislacyjne nie zwiększają prawdopodobieństwa merytorycznych uchybień na niekorzyść dziecka, nie gwarantują również powodzenia w procesie konstrukcji planu. W aktualnym stanie prawnym porozumienie małżonków ma charakter obligatoryjny jedynie w przypadku rodziców dążących do utrzymania pełnej władzy rodzicielskiej po orzeczeniu rozwodu. W pozostałych przypadkach przedłożenie planu uzależnione jest od woli stron postępowania. W przypadku rodziców, którzy nie wykazują nastawienia koncyliacyjnego i kwestię funkcjonowania dziecka cedują na sąd, usprawnienie regulacji pozostaje bez wpływu na przebieg postępowania i finalny kształt planu. Z systemu abstrakcyjnej kontroli sądowej i rejestru niedozwolonych postanowień mogą skorzystać, z kolei, małżonkowie dążący do możliwie samodzielnego i autonomicznego, w granicach prawa, ukształtowania sytuacji dziecka. W przypadku takiej postawy postulowane zmiany legislacyjne mogą skutkować wzrostem odpowiedniości ustaleń do rzeczywistych potrzeb dziecka, co poza osiągnięciem nadrzędnego celu instytucji porozumienia, jakim jest normatywne określenie 
sytuacji małoletniego w zgodzie z klauzulą jego dobra, sprzyja realizacji pozostałych funkcji planu.

\section{Bibliografia}

\section{Pozycje książkowe}

Bednarek M., Wzorce umów, [w:] System prawa prywatnego. Prawo zobowiazań - część ogólna, red. E. Łętowska, Warszawa 2013.

Kodeks cywilny. Komentarz, red. E. Gniewek, P. Machnikowski, Warszawa 2013.

Rozwód i separacja. Komentarz, red. J. Ignaczewski, Warszawa 2010. Wtadza rodzicielska i kontakty z dzieckiem. Komentarz, red. J. Ignaczewski, Warszawa 2012.

Walasik M., Analogia w prawie procesowym cywilnym, Warszawa 2013.

\section{Artykuly w pracach zbiorowych}

Araszkiewicz M., Łopatkiewicz A., Zienkiewicz A., Factors and Dimensions in the Parent Plan Support System, [w:] Transparenz. Tagungsband des 17. Internationalen Rechtsinformatik Symposions IRIS 2014, Hrsg. E. Schweighofer, F. Kummer, W. Hötzendorfer, Wien 2014, s. 103-111.

Araszkiewicz M., Łopatkiewicz A., Zienkiewicz A., Factor-Based Parent Plan Support System, [w:] ICAIL 2013 - The Fourteenth International Conference on Artificial Intelligence and Law. Proceedings of the Conference, ed. B. Verheij, E. Francesconi, A. Gardner, New York 2013, s. 171-175.

Łopatkiewicz A., Klauzula generalna dobra dziecka - wsparcie czy przeszkoda $w$ rozwiazywaniu konfliktów na tle rozwodowym?, [w:] Rozwiazywanie sytuacji konfliktowych $w$ wymiarze jednostkowym i społecznym, red. M. Plucińska, Poznań 2014, s. 145-157. Stojanowska W., Postulat przeniesienia koncepcji „planu wychowawczego” rozwodzacych się rodziców na grunt prawa polskiego, „Zeszyty Prawnicze UKSW" nr 7.2, Warszawa 2007, s. 7-44. 


\section{Akty prawne}

Dyrektywa Rady 93/13/EWG z dnia 5 kwietnia 1993 r. w sprawie nieuczciwych warunków w umowach konsumenckich.

Postanowienie Sądu Najwyższego z dnia 1 grudnia 2000 r. (V CKN 1747/00).

Recommendation No. R (84) 4 of the Committee of Ministers to Member States on Parental Responsibilities.

Rozporządzenie Rady Ministrów z dnia 19 lipca 2000 r. w sprawie wzoru rejestru postanowień wzorców umowy uznanych za niedozwolone (Dz.U. z 2000 r. Nr 723, poz. 62).

Rządowy projekt ustawy o zmianie ustawy - Kodeks rodzinny i opiekuńczy oraz niektórych innych ustaw z dnia 12 sierpnia 2008 r. (druk nr 888).

Ustawa z dnia 25 lutego 1964 r. Kodeks rodzinny i opiekuńczy (T.j. Dz.U. z 2012 r., poz. 788 ze zm.).

Ustawa z dnia 23 kwietnia 1964 r. Kodeks cywilny (T.j. Dz.U. z 2014 r., poz. 121 ze zm.).

Ustawa z dnia 17 listopada 1964 r. Kodeks postępowania cywilnego (T.j. Dz.U. z 2014 r., poz. 101 ze zm.).

Ustawa z dnia 6 listopada 2008 r. o zmianie ustawy - Kodeks rodzinny i opiekuńczy oraz niektórych innych ustaw (Dz.U. z 2008 r. Nr 220, poz. 1431).

Ustawa z dnia 6 stycznia 2000 r. o Rzeczniku Praw Dziecka (Dz.U. z 2000 r. Nr 6, poz. 69).

Wyrok Sądu Apelacyjnego w Warszawie z dnia 2 grudnia 2005 r. (VI ACa 760/05).

Wyrok Sądu Najwyższego z dnia 30 września 1980 r. (II CR 277/80).

\section{Pozycje internetowe}

Ciepła H., Nowelizacje Kodeksu rodzinnego i opiekuńczego z komentarzem, Lexis, Warszawa 2010.

Gromek K., Komentarz do artykutu 58 KRO, Wydawnictwo C.H. Beck, Legalis, Warszawa 2013. 
Pietrzykowski K., Komentarz do art. 385', Wydawnictwo C.H. Beck, Legalis, Warszawa 2013.

Sokołowski T., Komentarz do art. 58 KRO, Wolters Kluwer Polska, Warszawa 2013.

Trzaskowski R., Wild M., Kontrola abstrakcyjna wzorców umów w świetle badań sądowych, Instytut Wymiaru Sprawiedliwości, Warszawa 2012.

\section{Streszczenie}

Przedmiotem artykułu jest analiza instytucji planu wychowawczego tworzonego przez małżonków w toku postępowania rozwodowego. Punkt odniesienia dla rozważań nad porozumieniem o sprawowaniu władzy rodzicielskiej i utrzymywaniu kontaktów z dzieckiem po rozwodzie stanowi kodeksowa regulacja niedozwolonych postanowień umownych. Celem pracy jest próba teoretycznej modyfikacji modelu planu wychowawczego z zastosowaniem wybranych rozwiązań optymalizacyjnych stosowanych na gruncie problematyki klauzul abuzywnych, ze wskazaniem potencjalnych korzyści dla uczestników postępowania rozwodowego, jak również trudności wynikających z ewentualnego wprowadzenia rozważanych zmian legislacyjnych.

Słowa kluczowe: prawo rodzinne, rozwód, konflikt, dziecko, plan wychowawczy, niedozwolone postanowienia umowne

\section{Summary}

The institution of agreement of spouses on exercising parental authority and maintaining contacts with the child after the divorce in the context of the regulation of unfair contract terms

The topic of the paper is the analysis of the institution of parenting plan developed by the spouses in the course 
of divorce proceedings. The point of reference for the investigations, concerning the agreement on exercising parental authority and maintaining contacts with the child, is given by the regulation of unfair contact terms as provided in the Civil Code. The aim of the work is an attempt of theoretical modification of the model of parenting plan by means of application of certain optimizing solutions applied in the context of unfair contract terms, with indication of potential benefit for the parties of the divorce proceedings as well as with pointing out the difficulties arising from the investigated legislative solutions.

Keywords: family law, divorce, conflict, child, parenting plan, unfair contract terms

Agata Łopatkiewicz, Instytucja porozumienia małżonków o sposobie wykonywania władzy rodzicielskiej $i$ utrzymywaniu kontaktów $z$ dzieckiem po rozwodzie w kontekście kodeksowej regulacji niedozwolonych postanowień umownych, [w:] Pedagogiczne konteksty społecznego wsparcia rodziny, red. ks. Grzegorz Godawa, Kraków 2015, s. 241-278.

DOI: http://dx.doi.org/10.15633/9788374384247.08 